\title{
Studies on Wear Behaviour of Coated RHA-TIO2-LM24 Aluminium Alloy Composite
}

\author{
Chandar"1, Dr. G Harish ${ }^{2}$, Gujjala Anil Babu ${ }^{3}$, Puneeth P ${ }^{4}$, Dr. H K Shivanand \\ ${ }^{\# 1}$ Research Scholar, Mechanical Engineering, UVCE, Bangalore University, Bengaluru, Karnataka, India. \\ \#2Professor, Mechanical Engineering, UVCE, Bangalore University, Bengaluru, Karnataka, India. \\ *3Senior Manager, Methods Engineering Dept. HAL, Bangalore, India. \\ ${ }^{* 4}$ PG Scholar, Mechanical Engineering, UVCE, Bangalore University, Bengaluru, Karnataka, India. \\ ${ }^{\text {*5} P r o f e s s o r, ~ M e c h a n i c a l ~ E n g i n e e r i n g, ~ U V C E, ~ B a n g a l o r e ~ U n i v e r s i t y, ~ B e n g a l u r u, ~ K a r n a t a k a, ~ I n d i a . ~}$
}

Article Info
Volume 8, Issue 5
Page Number : 309-319
Publication Issue
September-October-2021

\section{Article History}

Accepted : 01 Oct 2021

Published : 07 Oct 2021

\section{ABSTRACT}

Liquid metallurgy method based aluminium matrix composites (AMCs) are extensively utilized in diverse engineering applications including shipbuilding, structural, non-structural, automotive, and aerospace owing to their superior strength, weightless, low density, excellent corrosion, and wear resistance. In the present research work, liquid state technique is employed to prepare the LM4/RHA/TiO2 composites containing four different mass proportion of RHA and TiO2. The weight proportion of reinforcements ie RHA-1,3\&5 and TiO2 2,5\&6 respectively.From the dry sliding wear studies, it is evident that the incorporation of RHA and TiO2 particles into the LM24 aluminium matrix alloy increases the wear resistance properties up to $45 \%$ as compared with the dry sliding behaviour of pure aluminium LM4 alloy. Dry sliding wear results revealed that the parameters like varying weight percentage, sliding speed, and applied load are the direct impact on the wear behaviour of the hybrid composites. A reduction of up to $34 \%$ wear rate was observed by incorporation of $5 \%$ of RHA and $1 \%$ \& $6 \%$ of $\mathrm{TiO} 2$ particles as compared with the remaining percentage of reinforcements. The developed Coated RHA-TIO2 -LM24 aluminum alloy composite exhibits excellent mechanical properties, can be used in long-term applications in which saving weight is an important feature, such applications include and automotive engine parts and aerospace industry. In automotive industry, it can be used for making Brake disc, Turbo-compressors, Pump supporting parts, rear axle, differential housing.

Keywords : LM4/RHA/TiO2, wear, Pin and Disc, And Rice husk. 


\section{INTRODUCTION}

Aluminium alloys have excellent mechanical properties coupled with good corrosion resistance. However, they possess poor wear and seizure resistance. To improve the above said properties, researchers have successfully dispersed various hard and soft reinforcements such as $\mathrm{SiO} 2, \mathrm{SiC}, \mathrm{Al} 2 \mathrm{O} 3$, flyash, glass, WC, graphite, mica, and coconut shell char in aluminium alloys by different processing routes. Of all the processing routes, liquid metallurgy method is the most sought after owing to its several advantages such as economical mass production, near net shaped components can be produced. In recent years, aluminium alloy-based metal matrix composites (MMCs) are being explored as candidate materials in several interesting applications such as piston, connecting rod, contactors, where sliding is a key component.

Aluminium alloys (or aluminium alloys; see spelling differences) are alloys in which aluminium (Al) is the predominant metal. The typical alloying elements are copper, magnesium, manganese, silicon, tin and zinc. There are two principal classifications, namely casting alloys and wrought alloys, both of which are further subdivided into the categories heattreatable and non-heat-treatable. About $85 \%$ of aluminium is used for wrought products, for example rolled plate, foils and extrusions. Cast aluminium alloys yield cost-effective products due to the low melting point, although they generally have lower tensile strengths than wrought alloys. The most important cast aluminium alloy system is $\mathrm{Al}-\mathrm{Si}$, where the high levels of silicon (4.0-13\%) contribute to give good casting characteristics. Aluminium alloys are widely used in engineering structures and components where light weight or corrosion resistance is required.
Presently, aluminium based reinforced metal matrix composites have huge demand and keen attention by researchers due to its light weight, high strength and high stiffness. Aluminium metal matrix finds a wide range of applications in aerospace, automotive, marine, rail etc. $\mathrm{SiC}$ and $\mathrm{Al} 2 \mathrm{O} 3$ are the most commonly used ceramic materials for the reinforcement of Aluminium. A perfect replacement of the reinforcement materials $\mathrm{SiC}$ and $\mathrm{Al} 2 \mathrm{O} 3$ could be Boron Carbide due its high hardness. Nano materials are the cornerstones of nano science and nano technology. Nano structured science and technology is a broad and interdisciplinary area of research and development activities that has been growing explosively worldwide in past few years. It has the potential for revolutionizing the way in which the material and the products are created. It is already having the significant commercial impact which will assuredly increase in future. Reinforcement of nano materials in the aluminium matrix will increase the mechanical properties of the material considerably.

Aluminium metal matrix can be fabricated through various methods such as liquid stir casting, powder metallurgy, spray deposition etc. Each fabrication method has different unique way for the fabrication. Based on the study of literature, liquid stir casting method is the most economical and suitable method for the fabrication of aluminium metal matrix composites. The reinforcement material binds together with the matrix material to carry the load and distributes the load to the individual reinforcement. The characterization of micro structures of the composite is necessary as the interface between the matrix material and the reinforcement material plays an important role in the metal matrix properties. The mechanical properties of the aluminium metal matrix composites can be 
increased by decreasing the size of the reinforcement material to nanometre. The objective of this work is to produce Al [LM24]- Risk Husk ash(RHA)/TiO2 composites with different proportion of RHA and TiO2, using liquid stir casting method. The fabricated composites were examined for structural and mechanical properties.

In recent time, commendable work has taken place in the field of Metal Matrix Composites. The results of which have shown us their tremendous capacity in enhancing the favourable properties of aluminium and its alloys. Metal matrixes with the suitable reinforcement have addressed a range of new requirements. A lot of work has been carried out in the field of E-Glass fibres reinforced aluminium matrix composites which makes it very clear that this combination is a very popular one. Al alloy matrix composite with homogeneous distribution of a variety of non-metallic particles and fibres ranging in size from $0.06 \mu \mathrm{m}$ to $800 \mu \mathrm{m}$ were racially fabricated, cast and hot extruded. Composites containing hard nonmetallic particles such as Ceramic, $\mathrm{TiC}, \mathrm{Al} 2 \mathrm{O} 3$, glass slag exhibited lower wear than the pure matrix alloy. Addition of E-Glass to the composites also gives good mechanical properties.

A lot of research has been done on aluminium alloy 1XXX to aluminum 6XXX based composites but research on LM24 based composites is very rare, also the properties of these composites are still not clear. Against this background, the present research work has been undertaken, with an objective to study the effect of different composition of reinforcement as Rice husk ash and TiO2on the LM24 based metal matrix composites.

\section{METHODS AND MATERIAL}

\section{A. MATERIALS.}

The reinforcement materials and matrix materials used in the present research are tabulated in table.
Table 2.1: Specifications of the materials used in the project work

\begin{tabular}{|c|c|}
\hline Sl No & Materials \\
\hline 01 & LM24 \\
\hline 02 & Rice Husk Ash \\
\hline 03 & TiO2 \\
\hline
\end{tabular}

B. Material Selection.

\section{LM 24:}

The selection of material is based on the properties, cost and the area of application where it is needed. In metal matrix composites, mostly pure aluminium are being used for its light weight and good corrosive resistance. Aluminium cast alloys have a great scope and application in the current scenario. Aluminium LM4 is selected as the base material which has high static load that are anticipated and creep extinction at elevated high temperature. This cast alloy conforms to BS $1490: 1988$ standards which contains silicon as the major constituent.

\section{Rice husk}

The RHA is obtained from rice husk which is an agricultural waste produced after removing the peels of rice crop. The removed peels are waste material but can be used as a suitable reinforcement particle through processing. The rice husk is organic in nature containing about $70-90 \%$ of matter in form of cellulose, lignin and minerals like silica, alkalis etc. Figure 1 shows rice husk.

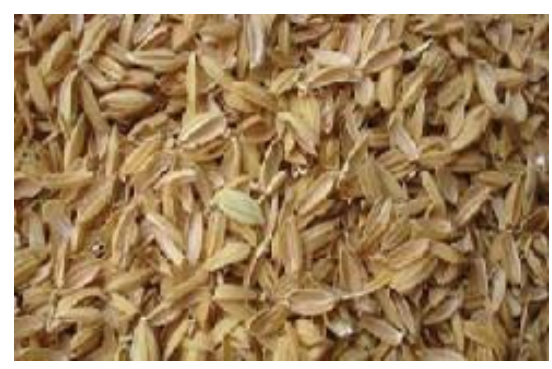

Fig 2.1: Risk Husk 


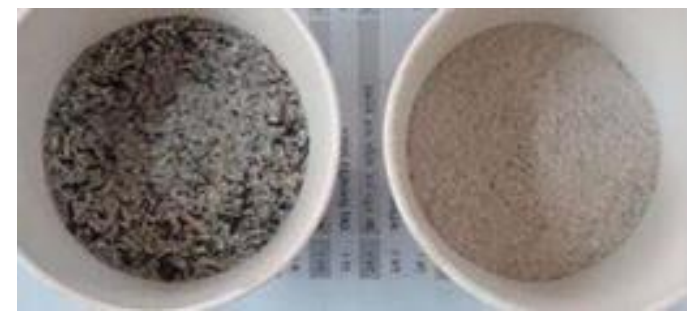

Fig 2.2: Coated Risk Husk ash

\section{Titanium dioxide (TiO2).}

Rutile is one of three forms of titanium dioxide (TiO2). It occurs in crystals, often in twins or rosettes, and is typically brownish red, although there are black varieties. Rutile is found in igneous and metamorphic rocks, chiefly in Switzerland, Norway, Brazil, and parts of the United States. Rutile is found naturally occurring in small quantities as impurities in iron oxide, chromium oxide and vanadium oxide. Rutile has a tetrahedral crystal structure (i.e. it has one fourfold axis) with $4 / \mathrm{m} 2 / \mathrm{m} 2 / \mathrm{m}$ symmetry. Its structure is made up of parallel chains of octahedrons, which are in turn composed of a titanium ion surrounded by six oxygen atoms. The model below shows the structure of the octahedron bases, although includes the unit cell edges.

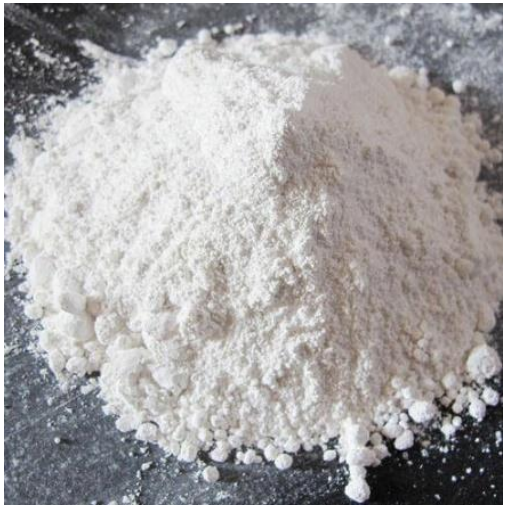

Fig $2.3: \mathrm{TiO}_{2}$

\section{EXPERIMENT}

\section{WEAR TEST}

This test method describes a laboratory procedure for determining the wear of materials during sliding using a pin-on-disk apparatus. Materials are tested in pairs under nominal non-abrasive conditions. The principle areas of experimental attention in using this type of apparatus to measure wear are described. The coefficient of friction may also be determined. The values stated in SI units are to be regarded as standard. This standard does not purport to address all of the safety concerns, if any, associated with it use. It is the responsibility of the user of this standard to establish appropriate safety and health practices and determine the applicability of regulatory limitations prior to use.
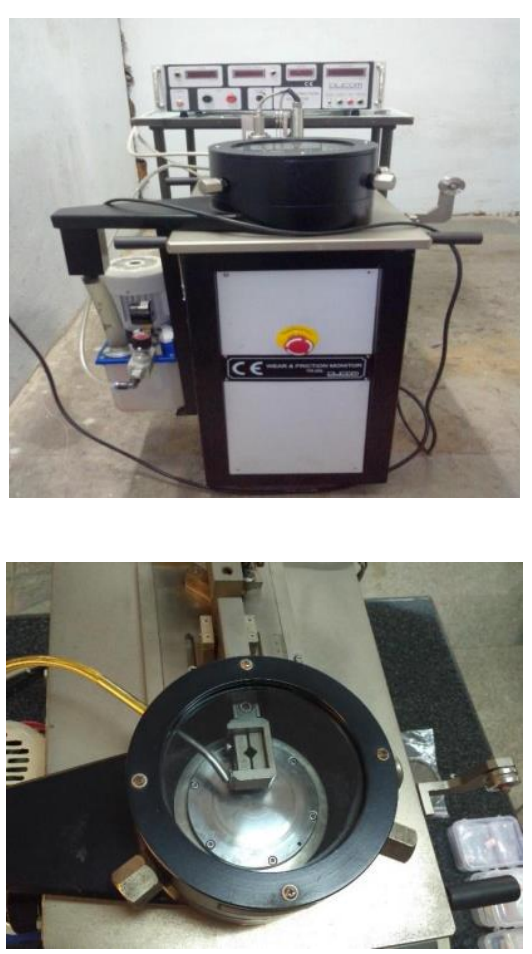

Fig 3.1: Pin on Disc Appartus.

The wear test was conducted using a pin-on-disc computerized wear testing machine as shown in figure in accordance with ASTM standards G99-95. The test uses the specimens of diameter of $6 \mathrm{~mm}$ and length $25 \mathrm{~mm}$ machined from the cast specimens.

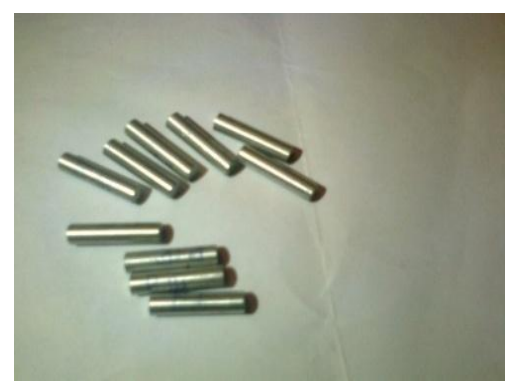

Fig 3.2: Wear Test Specimens. 


\section{IV.RESLTS AND DISCSSIONS.}

\section{Wear Test}

The wear test was conducted using a pin on disc test machine in accordance with ASTM standard G99-05. Keeping other conditions same, Aluminum alloy with varying percentage of $\mathrm{RHA}$ and $\mathrm{TiO} 2$ in were assessed for wear resistance. The Wear rate results of hybrid composite with different composition of reinforcement at different loads of 0.5 $\mathrm{Kg}, 1 \mathrm{Kg}$ and $1.5 \mathrm{Kg}$ with varying speed of 100,300 and $500 \mathrm{rpm} 20$ minutes' duration.

Table 4.1: Wear rate of LM24, RHA and TiO2 $\mathrm{MMC}$ at $0.5 \mathrm{Kg} 100 \mathrm{rpm}$

\begin{tabular}{|l|c|c|c|}
\hline Specimens & $2 \% \mathrm{TiO}_{2}$ & $4 \% \mathrm{TiO}_{2}$ & $6 \% \mathrm{TiO}_{2}$ \\
\hline 1\% Risk husk ash & 115 & 110 & 50 \\
\hline 3\% Risk husk ash & 85 & 70 & 40 \\
\hline 5\% Risk husk ash & 55 & 30 & 20 \\
\hline
\end{tabular}

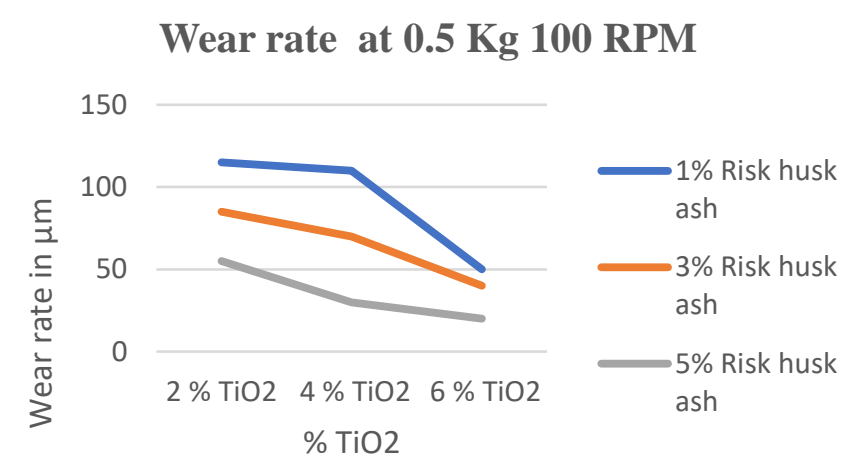

Fig 4.1: Wear rate of LM24, RHA and TiO2 MMC at $0.5 \mathrm{Kg} 100 \mathrm{rpm}$

Table 4.2: Wear rate of LM24, RHA and TiO2 $\mathrm{MMC}$ at $0.5 \mathrm{Kg} 300 \mathrm{rpm}$

\begin{tabular}{|l|c|c|c|}
\hline Specimens & $2 \% \mathrm{TiO}_{2}$ & $4 \% \mathrm{TiO}_{2}$ & $6 \% \mathrm{TiO}_{2}$ \\
\hline 1\% Risk husk ash & 160 & 130 & 110 \\
\hline 3\% Risk husk ash & 115 & 95 & 70 \\
\hline $5 \%$ Risk husk ash & 80 & 60 & 40 \\
\hline
\end{tabular}

Wear rate at $0.5 \mathrm{Kg} 300 \mathrm{RPM}$

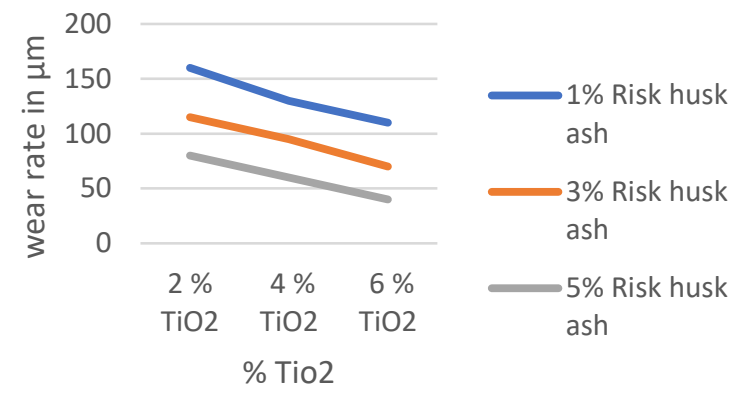

Fig 4.2: Wear rate of LM24, RHA and TiO2 MMC at $0.5 \mathrm{Kg} 300 \mathrm{rpm}$

Table 4.3: Wear rate of LM24, RHA and TiO2 $\mathrm{MMC}$ at $0.5 \mathrm{Kg} 500 \mathrm{rpm}$

\begin{tabular}{|l|c|c|c|}
\hline Specimens & $2 \% \mathrm{TiO}_{2}$ & $4 \% \mathrm{TiO}_{2}$ & $6 \% \mathrm{TiO}_{2}$ \\
\hline 1\% Risk husk ash & 190 & 175 & 145 \\
\hline 3\% Risk husk ash & 150 & 160 & 105 \\
\hline 5\% Risk husk ash & 120 & 25 & 15 \\
\hline
\end{tabular}

Wear rate at $0.5 \mathrm{Kg} 500 \mathrm{RPM}$

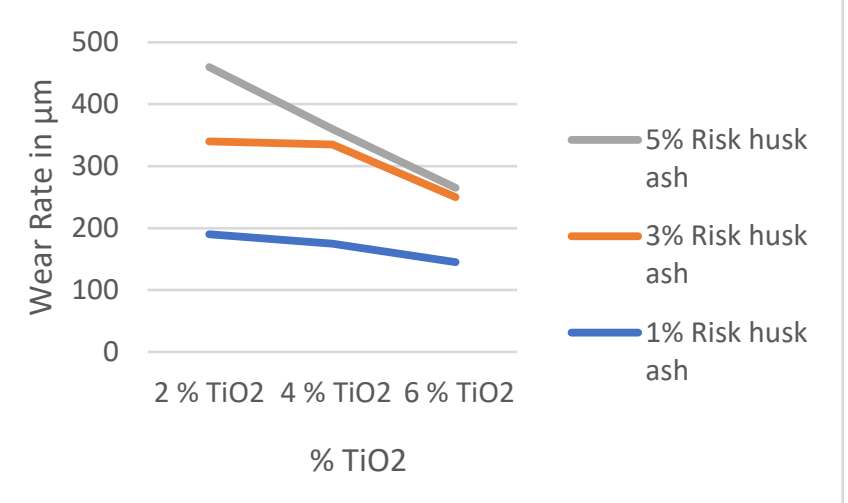

Fig 4.3: Wear rate of LM24, RHA and TiO2 MMC at $0.5 \mathrm{Kg} 500 \mathrm{rpm}$

Table 4.4: Wear rate of LM24, RHA and TiO2 $\mathrm{MMC}$ at $1 \mathrm{Kg} 100 \mathrm{rpm}$

\begin{tabular}{|l|c|c|c|}
\hline Specimens & $2 \% \mathrm{TiO}_{2}$ & $4 \% \mathrm{TiO}_{2}$ & $6 \% \mathrm{TiO}_{2}$ \\
\hline 1\% Risk husk ash & 215 & 195 & 160 \\
\hline 3\% Risk husk ash & 165 & 130 & 95 \\
\hline $5 \%$ Risk husk ash & 110 & 85 & 60 \\
\hline
\end{tabular}




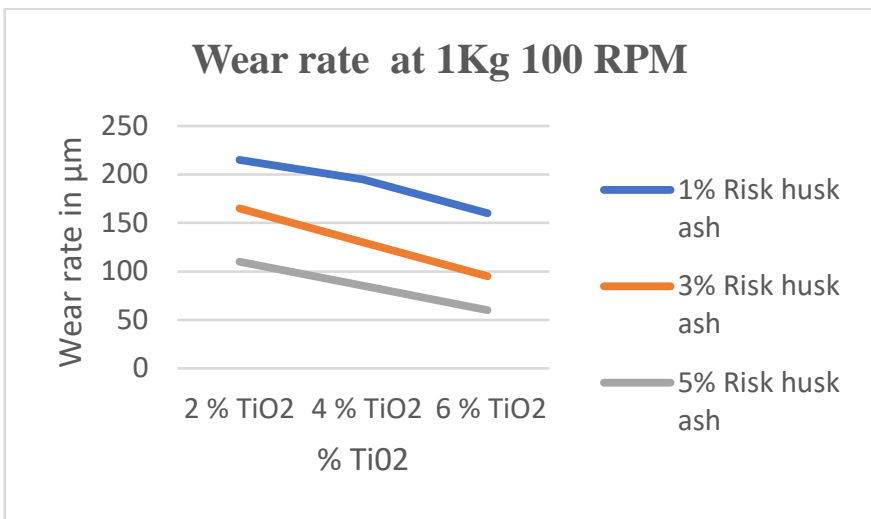

Fig 4.4: Wear rate of LM24, RHA and TiO2 MMC at $1 \mathrm{Kg} 100 \mathrm{rpm}$

Table 4.5: Wear rate of LM24, RHA and TiO2 MMC at $1 \mathrm{Kg} 300 \mathrm{rpm}$

\begin{tabular}{|l|c|c|c|}
\hline Specimens & $2 \% \mathrm{TiO}_{2}$ & $4 \% \mathrm{TiO}_{2}$ & $\begin{array}{c}6 \% \\
\mathrm{TiO}_{2}\end{array}$ \\
\hline 1\% Risk husk ash & 280 & 265 & 215 \\
\hline 3\% Risk husk ash & 245 & 175 & 130 \\
\hline $5 \%$ Risk husk ash & 150 & 110 & 75 \\
\hline
\end{tabular}

Wear rate at $1 \mathrm{Kg} 300 \mathrm{RPM}$

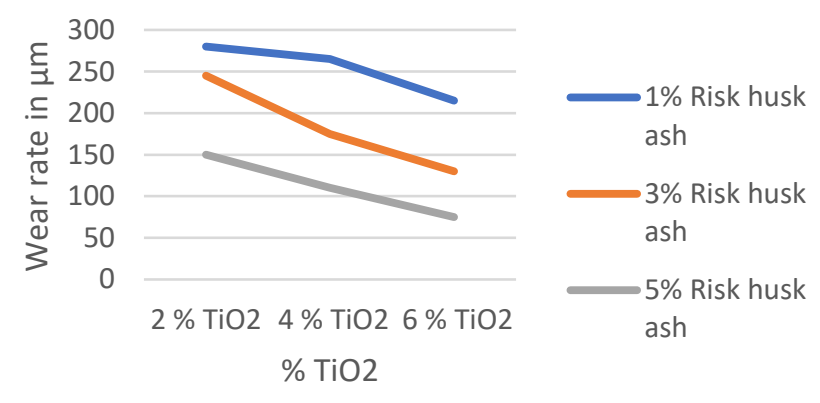

Fig 4.5: Wear rate of LM24, RHA and TiO2 MMC at $1 \mathrm{Kg} 300 \mathrm{rpm}$

Table 4.6: Wear rate of LM24, RHA and TiO2 MMC at $1 \mathrm{Kg} 500 \mathrm{rpm}$

\begin{tabular}{|l|c|c|c|}
\hline Specimens & $2 \% \mathrm{TiO}_{2}$ & $4 \% \mathrm{TiO}_{2}$ & $\begin{array}{c}6 \% \\
\mathrm{TiO}_{2}\end{array}$ \\
\hline 1\% Risk husk ash & 340 & 310 & 285 \\
\hline 3\% Risk husk ash & 320 & 260 & 200 \\
\hline 5\% Risk husk ash & 235 & 180 & 130 \\
\hline
\end{tabular}

Wear rate at $1 \mathrm{Kg} 500 \mathrm{RPM}$

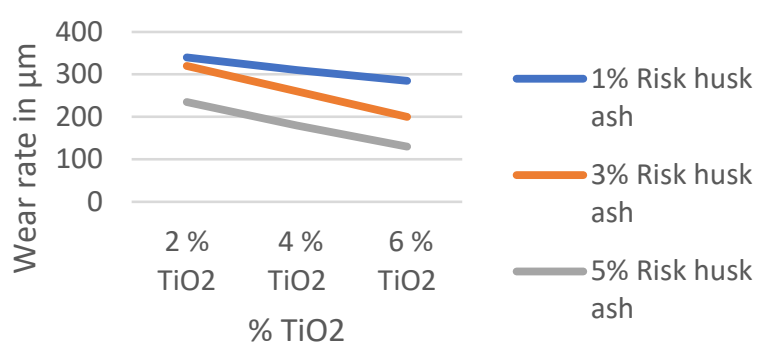

Fig 4.6: Wear rate of LM24, RHA and TiO2 MMC at $1 \mathrm{Kg} 500 \mathrm{rpm}$

Table 4.7: Wear rate of LM24, RHA and TiO2 $\mathrm{MMC}$ at $1.5 \mathrm{Kg} 100 \mathrm{rpm}$

\begin{tabular}{|l|c|c|c|}
\hline Specimens & $2 \% \mathrm{TiO}_{2}$ & $4 \% \mathrm{TiO}_{2}$ & $\begin{array}{c}6 \% \\
\mathrm{TiO}_{2}\end{array}$ \\
\hline 1\% Risk husk ash & 280 & 265 & 215 \\
\hline 3\% Risk husk ash & 245 & 175 & 130 \\
\hline 5\% Risk husk ash & 150 & 110 & 75 \\
\hline
\end{tabular}

Wear rate at $1.5 \mathrm{Kg} 100 \mathrm{RPM}$

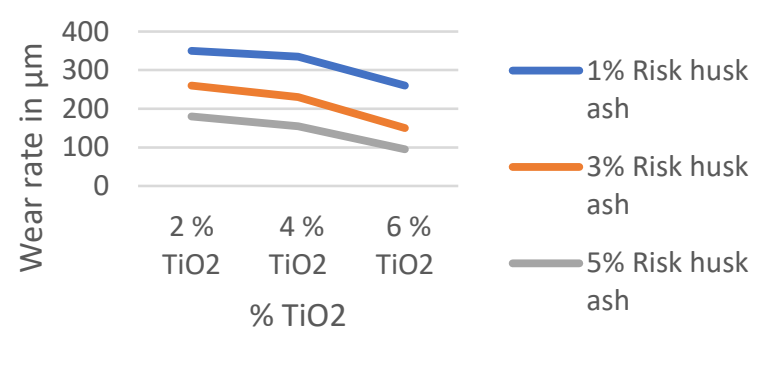

Fig 4.7: Wear rate of LM24, RHA and TiO2 MMC at $1.5 \mathrm{Kg} 100 \mathrm{rpm}$

Table 4.8: Wear rate of LM24, RHA and TiO2 MMC at $1.5 \mathrm{Kg} 300 \mathrm{rpm}$

\begin{tabular}{|l|c|c|c|}
\hline Specimens & $2 \% \mathrm{TiO}_{2}$ & $4 \% \mathrm{TiO}_{2}$ & $\begin{array}{c}6 \% \\
\mathrm{TiO}_{2}\end{array}$ \\
\hline 1\% Risk husk ash & 280 & 265 & 215 \\
\hline 3\% Risk husk ash & 245 & 175 & 130 \\
\hline 5\% Risk husk ash & 150 & 110 & 75 \\
\hline
\end{tabular}




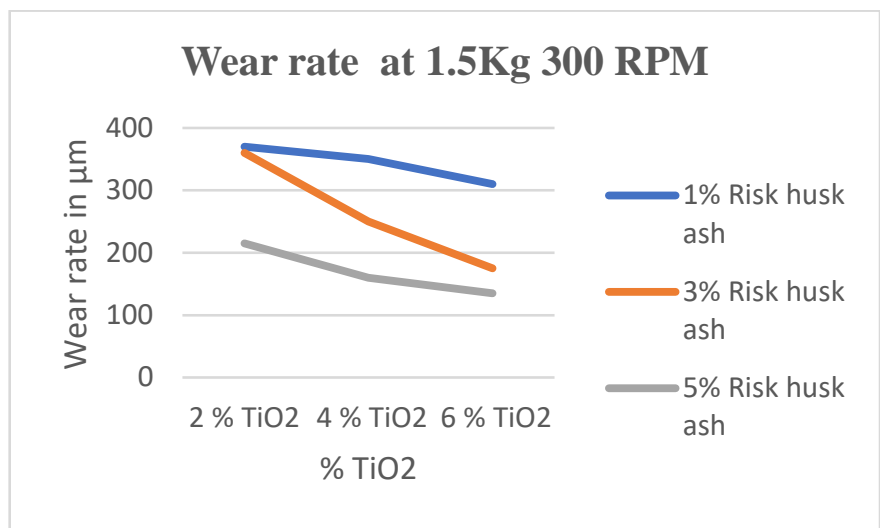

Fig 4.8: Wear rate of LM24, RHA and TiO2 MMC at $1.5 \mathrm{Kg} 300 \mathrm{rpm}$

Table 4.9: Wear rate of LM24, RHA and TiO2 $\mathrm{MMC}$ at $1.5 \mathrm{Kg} 500 \mathrm{rpm}$

\begin{tabular}{|l|c|c|c|}
\hline Specimens & $2 \% \mathrm{TiO}_{2}$ & $4 \% \mathrm{TiO}_{2}$ & $\begin{array}{c}6 \% \\
\mathrm{TiO}_{2}\end{array}$ \\
\hline 1\% Risk husk ash & 280 & 265 & 215 \\
\hline 3\% Risk husk ash & 245 & 175 & 130 \\
\hline 5\% Risk husk ash & 150 & 110 & 75 \\
\hline
\end{tabular}

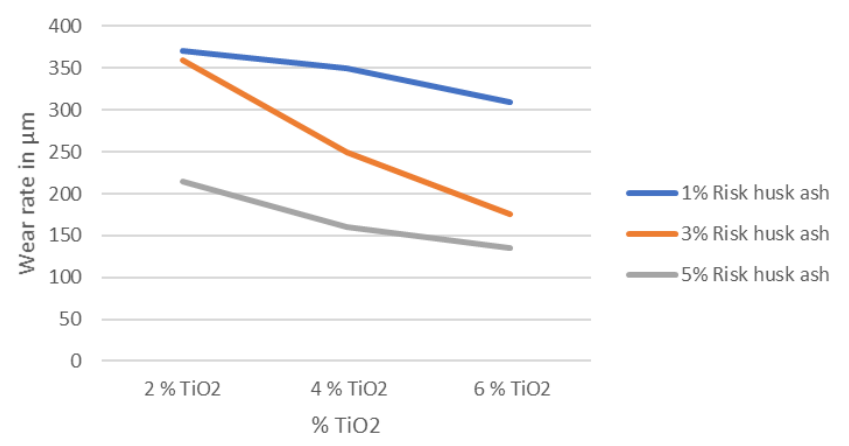

Fig 4.9: Wear rate of LM24, RHA and TiO2 MMC at $1.5 \mathrm{Kg} 500 \mathrm{rpm}$

The sever wear is serious problem with practical importance because the catastrophic nature of the wear in the post-transition region renders the tribocomponent like bearings and cylinder liner unfit for further use. However, sufficient is known about wear mechanisms and their solution to encourage greater application of knowledge.

The significant improvement in the wear resistance of composites in the present case may also be due to the size of the reinforcement used. It is generally found that the benefit of reinforcement are greater for small sized reinforcement than for larger, one reason being that the response of the composite to deform more was gradually reduce with increasing loads. This load dependence is explained by the observation that each individual abrasive particle transfers fewer loads for low applied loads. Each of the reinforcements is thus able to carry a larger portion of the loads it is exposed to from an individual abrasive particle. Consequently, the effect of the reinforcement on the composites wear resistance is better for low loads.

It is observed from the Graphs that the wear rate of the composites reduced with the increased in reinforcement content. The reduction in wear rate is by as much as 30 to $40 \%$ as the content of TiO2 (2 to $6 \%$ ) and RHA (1 to 5\%) varied. The improvement in wear resistance of the composites at low loads is attributed due to the presence of reinforcement, which form a thin film at the contact surface between the composite and the counter surface. The reinforcement fracture under higher loads forms a layer consisting of comminuted phase which provide protection against seizure. Thus the hybrid composites exhibit better wear resistance.

\section{CONCLUSION}

- Coated RHA and TiO2 reinforced MM24 hybrid composite is manufactured successfully.

- Hybrid composite with 3\% of RHA and 6\% of TiO2 showed the maximum Tensile strength of $298.37 \mathrm{~N} / \mathrm{mm}^{2}$.It is found that there is $37 \%$ increase of tensile strength while addition of RHA and TiO2 to LM 24.

- The aluminium based particulate reinforced composite, the dislocations are generated during solutionizing due to thermal mismatch between the matrix and the ceramic reinforcement particles.

- It can be inferred that the tensile strength increased with an increase in the weight percentage of rice husk ash and $\mathrm{TiO} 2$. Because, 
the RHA particles act as barriers to the dislocations when taking up the load applied.

- $\quad$ From the dry sliding wear studies, it is evident that the incorporation of $\mathrm{RHA}$ and $\mathrm{TiO} 2$ particles into the LM24 aluminium matrix alloy increases the wear resistance properties up to $45 \%$ as compared with the dry sliding behaviour of pure aluminium LM4 alloy.

- Dry sliding wear results revealed that the parameters like varying weight percentage, sliding speed, and applied load are the direct impact on the wear behaviour of the hybrid composites.

- A reduction of up to $34 \%$ wear rate was observed by incorporation of 5\% of RHA and $1 \%$ \& $6 \%$ of $\mathrm{TiO} 2$ particles as compared with the remaining percentage of reinforcements.

- At the same time, the sliding speed and load are directly proportional to the wear rate of the hybrid composites. As the sliding speed and load increases, the wear rate also increases drastically.Worn out analysis by using SEM revealed that the presence of different wear mechanisms like delamination, scratches, and grooves.

\section{REFERENCES}

[1]. Dr. B. Stalin, S. Arivukkarasan, P. Marish KumarMechanical Properties of Aluminium LM4 Metal Matrix Reinforced with Nano Boron CarbideAdvances in Natural and Applied Sciences. 11(4) April 2017, Pages: 479-483

[2]. Sachin T.S ans N.Mohan Wear Behavior of Aluminum LM4 Reinforced with WC and Ta/NbC Hybrid Nano-Composites Fabricated Through Powder Metallurgy Technique FME Transactions (2019) 47, 534-542

[3]. M R Shivakumar, NVR Naidu, Influence of Reinforcement Parameters on Thermal Conductivity of Lm6 Alloy/Soda Lime Glass Composites Through Taguchi's Orthogonal
Array Approach IJRET: International Journal of Research in Engineering and Technology Volume: 05 Special Issue: 16 | ICRAES-2016 | Sep-2016,

[4]. Narayan W. Mannurkar, Prasad U. Raikar, Investigation of Dry Sliding Wear Behaviour of LM4 (Al - Si5Cu3) T6/LM6 (Al-Si12)-M using Taguchi Approach, International Research Journal of Engineering and Technology (IRJET) Volume: 02 Issue: 04 | July-201

[5]. Puneeth H M, Girish K B, B H Vasudevamurthy, Experimental Investigation and Mechanical Behaviour of A356.1 Aluminium Alloy Matrix Composite Reinforced With Silicon Carbide International Research Journal of Engineering and Technology (IRJET) Volume: 02 Issue: 03 | June-2015

[6]. S. Ilangovan, Effects of Solidification Time on Mechanical Properties and Wear Behaviour of Sand Cast Aluminium Alloy. IJRET: International Journal of Research in Engineering and Technology Volume: 03 Issue: 02 | Feb-2014

[7]. Mr. Koushik P K Mr. Mahanthesh M. R. Mrs. Ramya C R Mr. Siddanth P Jain, Investigation on Mechanical Behavior of LM4 Alloys Reinforced with Soda Glass International Journal of Engineering Research \& Technology (IJERT) Volume 7, Issue 07 SSN: 2278-018

[8]. Miranda N. Alba-Baena1,, B.J. McKay,c, D.G. Eskin,d, S.H. Ko2, and J.S. Shin, Study of Mechanical Properties of an LM24 Composite Alloy Reinforced with Cu-CNT Nanofillers, Processed Using Ultrasonic Cavitation Materials Science Forum Vol. 765 (2013) pp 245-249

[9]. R. Senthil Kumar M. Thiagarajan, and K. Chandrasekaran3 Investigation of Mechanical and Wear Properties of LM24/Silicate/Fly Ash Hybrid Composite Using Vortex Technique Advances in Materials Science and Engineering Volume 2016, Article ID 6728237, 8 pages 
[10]. Harvinder Singh, Gurdyal Singh, Anoop Aggarwal Impact Strength of RHA and Fly Ash Based Aluminum Composites IJRMET Vol. 4, Issue 2, Spl - 2 May - October 2014 pp 143-145 Rajshahi University Journal of Science \& Engineering ISSN 2309-0952

[11]. Munusamy Arulraj1, Ponnusamy Kumaraswamy Palani2, Lakshmikanthan Venkatesh3 optimization of machining parameters in turning of Hybrid aluminiummatrix (lm24-sicp-coconut shell Ash) composite Materials and technology 53 (2019) 2, 263-268

[12]. Kartik Gupta Mechanical Behavior of Aluminium (AA6061) Reinforced with Alumina,Rice Husk Ash Materials, Mechanics \& Modeling (NCMMM-2020) AIP Conf. Proc. 2341, 040020-1-040020-21; https

[13]. S.D.Saravanana*, M.Senthil Kumarb Effect of Mechanical Properties on Rice Husk Ash Reinforced Aluminum alloy (AlSi10Mg) Matrix Composites. International Conference On DESIGN AND MANUFACTURING, IConDM 2013 Procedia Engineering 64 ( 2013 ) 1505 1513

[14]. Neelima Devi Chinta\#1, K. Srinivasa Prasad\#2, V. Mani Kumar Characterization of Rice Husk Ash and SiC Reinforced Aluminium Metal Matrix Hybrid Composite \#3 SSRG International Journal of Mechanical Engineering (SSRG-IJME) - Special Issue May 2017,pp 329-332

[15]. Md. Hasibul Haque, Ramin Ahmed, Md. Muzahid Khan, Shadman Shahriar Fabrication, Reinforcement and Characterization of Metal Matrix Composites (MMCs) using Rice Husk Ash and Aluminium Alloy (A-356.2) International Journal of Scientific \& Engineering Research, Volume 7, Issue 3, March-2016 pp 28-35

[16]. Chinnamahammad Bhasha, K. Balamurugan* Studies on mechanical properties of
Al6061/RHC/TiC hybrid composite* International Journal of Lightweight Materials and Manufacture 4 (2021) 405e415

[17]. Anwesh k. Virkunwar a, Shouvik Ghosh b, Ranjan Basak c, A. S. Rao d Study of Mechanical and Tribological Characteristics of Aluminium Alloy Reinforced with Rice Husk Ash

[18]. R. Karthigeyan, G. Ranganath, S. Sankaranarayanan "Mechanical Properties and Microstructure Studies of Aluminium (7075) Alloy Matrix Composite Reinforced with Short Basalt Fibre" European Journal of Scientific Research, ISSN 1450-216X Vol.68 No.4 (2012), pp. 606- 615.

[19]. P. Pradeep, P. S. Samuel Ratna Kumar, Daniel Lawrence I, Jayabal S "Characterization of par particulate reinforced Aluminium 7075 / TiB2 Composites" International Journal of Civil Engineering and Technology (IJCIET), Volume 8, Issue 9, September 2017, pp. 178-190.

[20]. Arunkumar D T , Raghavendra Rao P S, Mohammed Shadab Hussain, Naga Sai Balaji P $\mathrm{R}$ "Wear Behaviour and Microstructure Analysis of Al-7075 alloy reinforced with Mica and Kaolinite" IOP Conf. Series: Materials Science and Engineering 376 (2018) 012067.

[21]. Rajesh Kumar Bhushan, Sudhir Kumar and S. Das, "Fabrication and characterization of 7075 $\mathrm{Al}$ alloyreinforced with $\mathrm{SiC}$ particles", International Journal of Advanced Manufacturing Technology, No. 65, pp. 611624, 2013.

[22]. Madhuri Deshpande, Rahul Waikar, Ramesh Gondil, S.V.S Narayan Murty, T.S.Mahata "Processing of Carbon fiber reinforced Aluminium (7075) metal matrix composite" International Journal of Advanced Chemical Science and Applications (IJACSA), ISSN (Online): 2347-761X, Volume -5, Issue -2, 2017.

[23]. Manoj Singla, D. Deepak Dwivedi, Lakhvir Singh, Vikas Chawla "Development of Aluminium Based Silicon Carbide Particulate 
Metal Matrix Composite"Journal of Minerals \& Materials Characterization \& Engineering, Vol. 8, No.6, pp 455-467, 2009.

[24]. Jamaluddin Hindi, Achuta Kini U, S.S Sharma "Mechanical Characterisation of Stir Cast Aluminium7075 Matrix Reinforced ith Grey Cast Iron \& Fly Ash" International Journal of Mechanical And Production Engineering, ISSN: 2320-2092. Volume- 4, Issue-6, Jun.- 2016.

[25]. Mohan Kumar S, Pramod R, Shashi Kumar M E, Govindaraju H K "Evaluation of Fracture Toughness and Mechanical Properties of Aluminum Alloy 7075, T6 with Nickel Coating” ScienceDirect, Procedia Engineering 97 (2014) $178-185$.

[26]. Gururaj Aski, Dr. R. V. Kurahatti "The effect of Mechanical properties and microstructure of LM13Aluminum Alloy Reinforced with Zirconium silicate(ZrSiO4)" International Journal of InnovativeResearch in Science, Engineering and Technology" Vol. 6, Issue 6, June 2017.

[27]. Savannah, V. S. Ramamurthy "Microstructure and Wear Characterization of A356- ZrSio4 Particulate Metal Matrix Composite” International Journal of Science and Research (IJSR), Volume 3 Issue 7, July 2014.

[28]. R.S. Raveendra, P.V. Krupakara, P.A. Prashanth, B.M. Nagabhushana "Enhanced Mechanical Properties of Al- 6061 Metal Matrix Composites Reinforced with $\alpha-\mathrm{Al} 2 \mathrm{O} 3$ Nanoceramics" journal of Materials Science \& Surface Engineering Vol. 4 (7), 2016, pp 483487.

[29]. Miss. Laxmi1, Mr. Sunil Kumar2 "Fabrication and Testing of Aluminium 6061 Alloy \& Silicon Carbide Metal Matrix Composites" International Research Journal of Engineering and Technology (IRJET) Volume: 04 Issue: 06 | June-2017.

[30]. Z. Hasan, R. K. Pandey, D.K. Sehgal "Wear Characteristics in Al-SiC Particulate Composites and the Al-Si Piston Alloy" Journal of Minerals \& Materials Characterization \& Engineering, Vol. 10, No.14, pp.1329-1335, 2011.

[31]. Bhoopathiraam c, Sreenivas Rao K.V, Vasudeva $B$ "Effect of boron carbide reinforcement onaluminium matrix composites" IJMMSE, ISSN 2278-2516, Vol.3, Issue 1, Mar 2013, 41-48

[32]. G.B. Veeresh Kumar, an Introduction to Metal Matrix Composites, Cambridge University Press, Cambridge, UK, 1993, pp. 166-217.

[33]. Muhammad Hayat Jokhio*, Muhammad Ibrahim Panhwar (2011) "Manufacturing of Aluminum Composite Material UsingStir Casting Process" mehran university research journal of engineering \& technology, volume 30, no. 1, january, 201

[34]. A. Ahmed, A.J. Neely, K. Shankar, P. Nolan, (2010), "Synthesis, Tensile Testing, and Microstructural Characterization of Nanometric SiC Particulate-Reinforced Al 7075 MatrixComposites", Metallurgical And Materials Transactions A, 1582-Volume 41a, June 2010.

[35]. Hossein Bisadi, Asghar Abasi, (2011), Fabrication of Al7075/TiB2 Surface Composite Via Friction Stir Processing",American Journal of Materials Science. 2011; 1(2): 6770.Prabhakar Kammer1, H.K.Shivanand2(2012) "Experimental Studies On Mechanical Properties Of E-Glass Short Fibres \& Fly Ash Reinforced Al 7075 Hybrid Metal Matrix Composites"International Journal of Mechanical and Industrial Engineering (IJMIE), ISSN No.2231-6477, Vol-1 Issue-4, 2012

[36]. Deepak Singla1, S.R. Mediratta,( 2013) "Evaluation Of Mechanical Properties Of $\mathrm{Al}$ 7075-Fly Ash Composite Material" International Journal of Innovative Research in Science, Engineering and Technology Vol. 2, Issue 4, April 2013

[37]. R.Ramesh, N.Murugan,(2012) "Production and Characterizationof Aluminium 7075 - T651 
Alloy / B4C Surface Composite by Friction Stir Processing" International Journal of Engineering and Advanced Technology (IJEAT) ISSN: 2249 - 8958, Volume-2, Issue-1, October 2012.

[38]. Ravinder Kumar, Suresh Dhiman,(2013) “A study of sliding wear behaviors of Al-7075 alloy and Al-7075 hybrid composite by response surface methodology analysis", ELSEVEIR Materials and Design 50 (2013) 351-359

[39]. Arjun Haridas, Ravikumar M, Uvaraja V C, (2013), "Production And Wear Analysis Of Aluminium Metal Matrix Composite", International Journal Of Innovative Research \& Development,March, 2013 Vol 2 Issue 3

[40]. T Senthilvelan ,S Gopalakannan, S Vishnuvarthan (2013), “Fabrication and Characterization of $\mathrm{SiC}, \mathrm{Al} 2 \mathrm{O} 3$ and $\mathrm{B} 4 \mathrm{C}$ Reinforced Al-Zn-Mg-Cu Alloy (AA 7075) Metal Matrix Composites: A Study", Advanced Materials Research Vols. 622- 623 (2013) pp 1295-1299, Trans Tech Publications,Switzerland

[41]. S.Gopalakannan ,T.Senthilvelan, (2013)“ Application of response surface method on machining of Al-SiC nanocomposites", ELSEVEIR Measurement 46 (2013) 2705-2715

[42]. Baradeswaran „, A. Elaya Perumal (2013), "Study on mechanical and wear properties of $\mathrm{Al}$ 7075/Al2O3/graphite hybrid composites", ELSEVEIR Composites: Part B 56 (2014) 464471

[43]. K.Gajalakshmi1, S.Kathiresan2, K.S.Sreenivasan (2014), "Investigation of Microstructure and Mechanical Properties af Silicon Nitride reinforced AMMC using stir casting method", IOSR Journal of Mechanical and Civil Engineering (IOSRJMCE) e- ISSN: 2278-1684, p-ISSN : 2320-334X PP 61-65.

[44]. Raghavendra N1, V S Ramamurthy, (2014), "Effect of Particle Size and Weight Fraction of Alumina Reinforcement on Wear Behavior of Aluminum Metal Matrix Composites"
International Journal of Innovative Research in Science, Engineering and Technology Vol. 3, Issue 4, April 2014

[45]. A.Sert, O.N.Cellik (2014), "Wear Behaviour of Sic Reinforced Surface Composite Al7075-T651 aluminium alloy produced using Friction Stir Processing", Indian Journal of Engineering \& Material Science, Vol 21 February 2014, pp 3543

[46]. Vrk Rao Nallu Ramanaiah Mohammed Sarcar Dry Sliding Wear Behavior of Al7075 Reinforced with Titanium Carbide (TiC)Particulate Composites Proceedings of International Conference on Advances in Materials, Manufacturing and Applications (AMA 2015), April 9-11, 2015.

[47]. G.K.Kiran Kumar, C.Bhavani Sankar, Mechanical Behaviour of Silicon Carbide(Sic) / Fly Ash particles Reinforced Aluminium-7075 Based Metal Matrix Composite Fabricated By Stir Casting Method, IJSART - Volume 5 Issue 2 - February 2019.pp-527-534

[48]. Jamaluddin Hindi,AchutaKini U,S.S Sharma ,Mechanical Characterisation Of Stir Cast Aluminium 7075 Matrix Reinforced With Grey Cast Iron \& Fly Ash ,Volume- 4, Issue-6, Jun.16,pp-127-132.

[49]. Dr.SumathyMuniamuthu,Dr. Naga Lingeswara Raju, S. Sathishkumar, K. Sunil Kumar,an Investigation on mechanical properties of al 7075-al2o3 metal matrix composite, International Journal of Mechanical Engineering and Technology (IJMET) Volume 7, Issue 6, 2016, pp.474-482.

[50]. K.Shirley and M.Nagabhushan,Analysis of mechanical properties and microstructure of al 7075-glass fibre mmc, IRJET, Volume: 05 Issue: 08,Aug 2018,pp-296-300.

[51]. Raghavendra N, V S Ramamurthy "Development and tribological characterization of dual particle and triple particle reinforced al7075/ al2o3 metal matrix composite," 
International Journal of Recent Advances in Mechanical Engineering (IJMECH) Vol.6, No.2, May 2017, pp. 11-22 M.

\section{Cite this article as :}

Chandar, Dr. G Harish, Gujjala Anil Babu, Puneeth P, Dr. H K Shivanand, "Studies on Wear Behaviour of Coated RHA-TIO2-LM24 Aluminium Alloy Composite", International Journal of Scientific Research in Science and Technology (IJSRST), Online ISSN : 2395-602X, Print ISSN : 2395-6011, Volume 8 Issue 5, pp. 309-319, September-October 2021. Available at

doi : https://doi.org/10.32628/IJSRST218540

Journal URL : https://ijsrst.com/IJSRST218540 